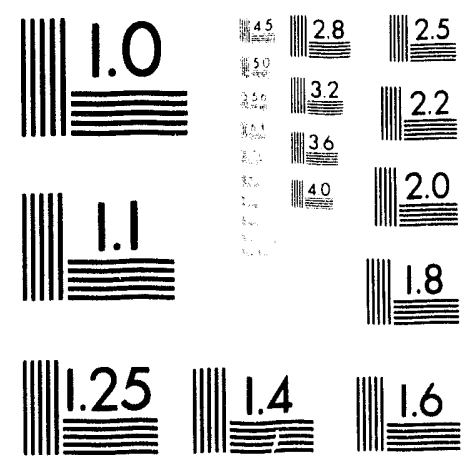



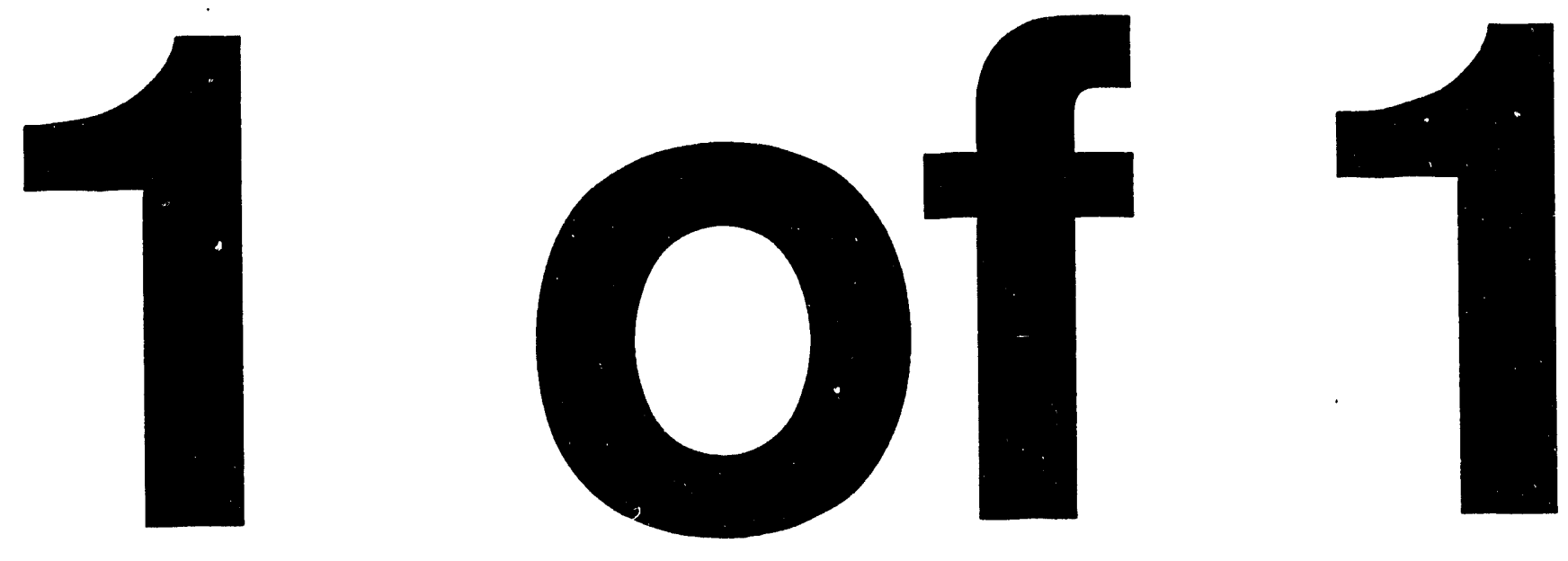


\section{A Preliminary Survey of Selected Structures on the Hanford Site for Townsend's Big-Eared Bat (Plecotus townsendii)}

J. M. Becker

October 1993

Prepared for the U.S. Department of Energy under Contract DE-AC06-76RLO 1830

Pacific Northwest Laboratory Richland, Washington 99352

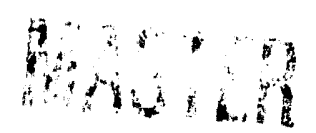




\section{Summary}

A preliminary survey of selected structures on the Hanford Site for Townsend's big-eared bat (Plecotus townsendii) was conducted by Pacific Northwest Laboratory (PNL) in August and September 1993. The Westinghouse Hanford Company (WHC) commissioned PNL to evaluate the potential for this bat, a candidate for federal protection, to occur in buildings potentially affected by decontamination and decommissioning operations under the Comprehensive Environmental Response, Compensation, and Liability Act (CERCLA).

The project involved identifying structures that contained bats and determining whether Townsend's big-eared bats were among those present. The survey focused on deactivated reactors, other buildings in the $100 \mathrm{D}$ and $100 \mathrm{~K}$ Areas, canyon buildings in the 200 Areas, and other structures reported to contain bats.

During this six-week survey, Townsend's big-eared bat was not located. However, some structures likely to contain bat colonies were unable to be surveyed and others were only partially surveyed. These require further investigation over a longer period of time before a final determination on this species can be made. Of the buildings surveyed, the reactors and their associated buildings provided roosting sites most used by bats. No bats were found in canyon buildings in the 200 areas. These buildings are occupied, well-lighted, and offer few entrances for bats. They are also probably too distant from the Columbia River Shureline, which constitutes the most important bat foraging habitat. We recommend that the remaining reactors and buildings, with emphasis on subterranean tunnels and basements, be surveyed during a more extended time period, i.e., June through September 1994. 


\section{Acknowledgments}

The survey for Townsend's big-eared bat (Plecotus townsendii) involved the cooperative efforts of Westinghouse Hanford Company (WHC) and Pacific Northwest Laboratory (PNL). WHC's Auxiliary Support Services directed by Dorman Blankenship, with its support staff of Health Physics Technicians (HPTs), were invaluable in scheduling surveys of decommissioned and deactivated buildings in the $100 \mathrm{D}$ Area. Scott Thoren provided photos of the bat colony below the DR Reactor. WHC's Inactive Facilities Surveillance and Maintenance group, directed by Jim Hodgson, and its HPT personnel were very helpful in scheduling surveys of deactivated nuclear reactors. 


\section{Contents}

Summary $\ldots \ldots \ldots \ldots \ldots \ldots \ldots \ldots \ldots \ldots \ldots \ldots \ldots \ldots \ldots \ldots \ldots$ iii

Acknowledgments $\ldots \ldots \ldots \ldots \ldots \ldots \ldots \ldots \ldots \ldots \ldots \ldots \ldots \ldots$

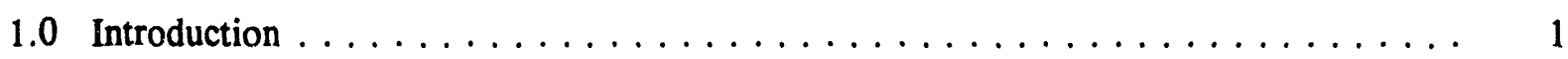

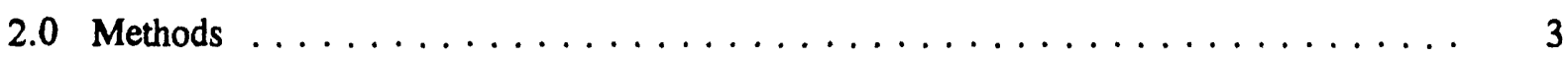

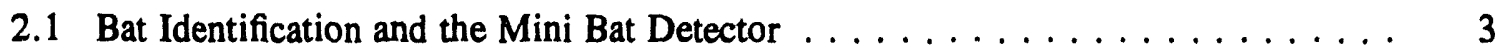

2.2 Recognition of Townsend's Big-Eared Bat Using Mini Bat Detectors . . . . . . . 3

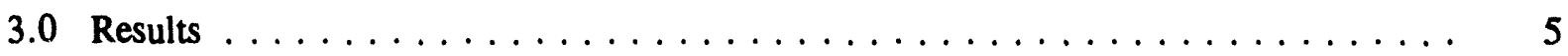

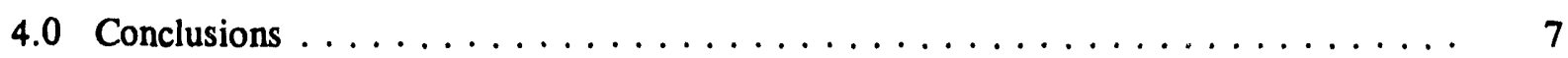

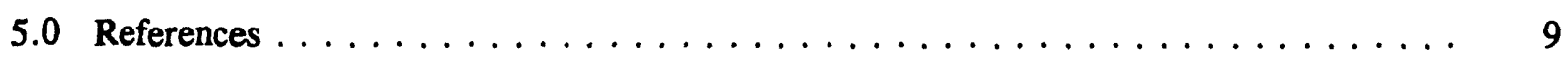

Appendix - Bats Recovered as Carcasses or Relocated by Animal Control

Operations, Westinghouse Hanford Company . . . . . . . . . . . . .

\section{Tables}

1 Roosting Habitat and Frequency Ranges for Search-Phase Echolocation Calls of Bat Species that may be Found on the Hanford Site

2 Results of Preliminary Survey for Fecal Deposits and Roosting Bats in Buildings in the 100D and 100K Areas, Deactivated Reactors, Canyon Buildings in the 200 Areas, and other Buildings Reported to Contain Bats 


\subsection{Introduction}

The Hanford Site offers suitable habitat for insectivorous bats. The Columbia River and Rattlesnake Springs provide foraging habitat, and bats currently use some abandoned or little-used buildings as day roosts. Because of their nocturnal habits and a lack of formal studies of the local bat fauna, little is known about which species use these sites.

Fourteen bat species could potentially occupy the Hanford Site (Ingles 1965) (Table 1). All except the hoary bat may be present year-round (Thomas 1979). All except the Pallid bat (Antrozous pallidus) and Townsend's big-eared bat (Plecotus townsendii) forage primarily in riparian areas. The others forage primarily in upland habitats (Thomas 1979). All are nocturnal and orient themselves acoustically by ultrasonic echolocation calls. Townsend's big-eared bat, one of these 14 species, is a candidate for protection under the federal Endangered Species Act. It is a species of concern in connection with buildings scheduled for decontamination and decommissioning under the Comprehensive Environmental Response, Compensation, and Liability Act (CERCLA) (Fitzner et al. 1992). Westinghouse Hanford Company (WHC) commissioned Pacific Northwest Laboratory (PNL) to conduct a survey of Townsend's big-eared bat in abandoned buildings of the reactor areas and in canyon buildings of the 200 Areas. The objective of this survey was to identify which of these structures contained bats and determine whether Townsend's big-eared bats were among those present.

Table 1. Roosting Habitat and Frequency Ranges for Search-Phase Echolocation Calls of Bat Species that may be Found on the Hanford Site ${ }^{(a)}$

\begin{tabular}{|c|c|c|c|c|}
\hline Species & Common Name & $\begin{array}{c}\text { Highest Frequency } \\
\text { (kHz) }\end{array}$ & $\begin{array}{c}\text { Lowest Frequency } \\
\text { (kHz) }\end{array}$ & $\begin{array}{c}\text { Roosting } \\
\text { Habitat (b),(c) }^{(2)}\end{array}$ \\
\hline Antrozus pallidus & Pallid bat & 49 & 26 & $\mathrm{Cl}, \mathrm{B}, \mathrm{C}$ \\
\hline Eptesicus fuscus & Big brown bat & 48 & 27 & $\mathrm{Cl}, \mathrm{B}, \mathrm{C}, \mathrm{T}$ \\
\hline Lasionycteris noclivagans & Silver-haired bat & -(d) & $25-30^{(e)}$ & $\mathrm{B}, \mathrm{T}$ \\
\hline Lasiurus cinereus & Hoary bat & 39 & $26 ; 20-25^{(e)}$ & $T$ \\
\hline Myotis californicus & California myotis & 67 & 37 & $\mathrm{Cl}, \mathrm{B}, \mathrm{T}$ \\
\hline Myotis evotis & Long-eared myotis & 97 & 54 & $\mathrm{~B}, \mathrm{~T}$ \\
\hline Myotis leibii & Small-footed myotis & - & - & $\mathrm{Cl}, \mathrm{B}, \mathrm{C}$ \\
\hline Myotis lucifugus & Little brown myotis & 78 & 38 & $\mathrm{Cl}, \mathrm{B}, \mathrm{T}$ \\
\hline Myotis thysanodes & Fringed myotis & 49 & 31 & $\mathrm{~B}, \mathrm{C}$ \\
\hline Myotis volans & Long-legged myotis & 90 & 40 & $\mathrm{~B}, \mathrm{~T}$ \\
\hline Myotis yumanensis & Yumi myotis & - & - & $\mathrm{B}, \mathrm{T}$ \\
\hline Pipistrellus hesperus & Western pipistrel $^{(f)}$ & 91 & 53 & $\mathrm{Cl}, \mathrm{B}, \mathrm{C}$ \\
\hline Plecotus tounsendii & Townsend's big-eared bat & 50 & 20 & $\mathrm{Cl}, \mathrm{B}, \mathrm{C}$ \\
\hline Tadarida molossa & Big frea-tailed bat & - & - & $\mathrm{B}, \mathrm{C}$ \\
\hline \multicolumn{5}{|c|}{$\begin{array}{l}\text { (a) Data from Van Zyll de Jong } 1985 \text {, unless otherwise noted. } \\
\text { (b) From Burt and Grossenheider } 1980, \text { Thomas } 1979, \text { Humphrey 1982, Jameson and Peeters } 1988 . \\
\text { (c) } \mathrm{B}=\text { roosts in buildings; } \mathrm{C}=\text { caves, } \mathrm{Cl}=\text { cliffs, } \mathrm{T}=\text { trees. } \\
\text { (d) No data available. } \\
\text { (e) From Fenton and Merriam } 1983 . \\
\text { (f) From Fenton and Bell } 1981 \text {. }\end{array}$} \\
\hline
\end{tabular}




\subsection{Methods}

\subsection{Bat Identification and the Mini Bat Detector}

The nocturnal habits of bats have generally limited species identification to examinations of dead animals or individuals captured in bat traps at roost entrances or in mist nets set over small bodies of water and along flyways. Recently, however, species identification has been made less labor-intensive and time-consuming by using ultrasonic bat detection devices. Because many bat species produce echolocation calls of differing frequencies and duration, ultrasonic detectors are a useful tool for species identification. Available equipment varies in sophistication, cost, and the amount and reliability of information that can be obtained from echolocations (Thomas and West 1984).

We used three Mini Bat Detectors, ${ }^{(a)}$ the device most often used in field studies. It uses a narrow-band microphone and heterodyning which "divides" intercepted frequencies by a factor of 10 , reducing inaudible ultrasound into the audible range. The output can be heard with headphones or recorded on a tape recorder. The Mini Bat Detector intercepts ultrasonic signals within a ca. $3-\mathrm{kHz}$ tunable window at any one time.

\subsection{Recognition of Townsend's Big-Eared Bat Using Mini Bat Detectors}

Sonograms, visual displays of frequency range and duration of search phase echolocations, have been constructed for various bat species. Sonograms, combined with the audible sounds produced by bat detectors, have been used to produce dichotomous keys for identification of some bat species (Fenton and Merriam 1983). However, no published dichotomous keys include Townsend's big-eared bat. Although a sonogram for this species has been published (Van Zyll de Jong 1985), the audible sounds produced by bat detectors used on this species are not well-documented.

A single search-phase echolocation from Townsend's big-eared bat may span up to a 30-kHz range (Table 1) and last only a few milliseconds. Bat "passes" (a sequence of calls emitted as an individual approaches an object) are generally less than, or equal to, 2 seconds (Thomas and West 1984). Because the Mini Bat Detector can only be tuned to one $3-\mathrm{kHz}$ window at a time, it would be impossible to simultaneously scan all the tuning frequencies necessary to characterize search-phase echolocations of Townsend's big-eared bat and thus differentiate it from other species. However, its lowest frequency, $20 \mathrm{kHz}$, extends $6 \mathrm{kHz}$ below any other species that may roost in buildings on the Hanford Site (Van Zyll de Jong 1985), (Table 1), making the, species potentially recognizable by setting detectors from $20-24 \mathrm{kHz}$.

We conducted a preliminary survey for fecal deposits and roosting bats in selected deactivated reactors, buildings in the $100 \mathrm{D}$ and $100 \mathrm{~K}$ Areas, canyon buildings in the 200 Areas, and other buildings reported to contain bats. Dead bats were collected and identified by their external features using a dichotomous key (Ingles 1965). Decomposed bats with unrecognizable external features were identified to the genus level using dental formulas (Ingles 1965). Areas that contained live bats were surveyed using Mini Bat Detectors. Additionally, a list of bats recovered as carcasses or relocated on the Hanford Site since 1991 was obtained from WHC's Animal Control Operations (see Appendix).

(a) Ultra Sound Advice, 23 Aberdeen Rd., London, England N5 2UG. 


\subsection{Results}

Two of the easternmost basins in the 100K East Area contain shallow water with emergent vegetation and substantial insect populations. They were surveyed on August 18, 1993, using two Mini Bat Detectors. The Mini Bat Detectors, coupled to tape recorders, were placed on walkways between the two basins and were set at $23 \mathrm{kHz}$ (with an accuracy of $\pm 1 \mathrm{kHz}$ ). The survey began at 2050 hours, just after sunset, and was terminated at 2250 hours. The recordings revealed no ultrasound emitted within the $22-24 \mathrm{kHz}$ window, the lower end of the frequency range for search-phase echolocations of Townsend's bigeared bat (Table 1). It may be that this species was not present during sampling or, if it was present, there are other explanations for why it was not detected. For example, it could have been too far from the detector for its echolocations to be recorded. The maximum distance at which echolocations can be detected is species-specific and dependent on the intensity of the call. Species emitting low-intensity calls can be detected only within approximately $2 \mathrm{~m}$ of the microphone, whereas species producing highintensity calls are detectable at least $10 \mathrm{~m}$ away (Fenton and Obrist 1990). Further, there is no published information on the range in which echolocations of Townsend's big-eared bat can be recorded. Again, if this species was present during sampling, its behavior may not have been "search-phase," but instead either "approach" or "feeding buzz" (the latter two stages of foraging behavior following searching), in which case it would likely have been echolocating at frequencies above $22-24 \mathrm{kHz}$. It may also be that the brief time the detector operated was insufficient to detect echolocations of this species.

A list of surveyed structures and survey results is found in Table 2. Of the buildings surveyed, bats appear to be most abundant in the F, H, DR, and D Reactors (Table 2). These reactors are unoccupied, dark, and provide entrances such as vents, pipes, and holes in exterior walls. Pallid bats seem to be most abundant, followed by bats of the genus Myotis, including the small-footed myotis and silver-haired bats (Table 2). No bats were located in canyon buildings of the 200 Areas, and Townsend's big-eared bat was not located in any of the surveyed structures (Table 2).

Subterranean portions of buildings where aboveground portions were completely surveyed (Table 2), particularly those known to contain bats such as the reactors, require investigation before a complete determination can be made on Townsend's big-eared bat. The F and DR Reactors were completely surveyed, including all radiologically controlled areas (RCAs) and surface contaminated areas (SCAs) (Table 2). Six dead pallid bats, 3 dead Myotis spp., 1 dead small-footed myotis, and 1 live unidentified bat were found in the F Reactor. Two dead silver-haired bats and 1 dead small-footed myotis were located in the DR Reactor (Table 2). Although no active colonies were found in these buildings, it is likely that they occur in tunnels and basements beneath the reactors. Areas such as caves, mines, and tunnels are typically used by bats during winter hibernation (Humphrey 1982). The process pipe tunnel between Building 190D and the DR Reactor contains an active bat colony of approximately 20 individuals, although the species has not yet been determined (Table 2).

A number of buildings were partially surveyed. These include RCAs in the $\mathrm{H}$ and D Reactors (Table 2). The $\mathrm{H}$ Reactor RCAs contained 7 dead pallid bats, 1 dead Myotis sp., and 1 live unidentified bat (Table 2). Three dead Myotis spp. were found in the D Reactor RCAs. The SCAs and underground portions of $\mathrm{H}$ and $\mathrm{D}$ Reactors should also be surveyed as they may contain active colonies. It is possible that different species may roost in different parts of the reactor. The RCAs of KW and KE Reactors were surveyed, and although no bats were located, a further survey of their SCAs and underground portions should be performed. 
Table 2. Results of Preliminary Survey for Fecal Deposits and Roosting Bats in Buildings in the $100 \mathrm{D}$ and $100 \mathrm{~K}$ Areas, Deactivated Reactors, Canyon Buildings in the 200 Areas, and Other Buildings Reported to Contain Bats

\begin{tabular}{|c|c|c|c|c|c|}
\hline Area/Reactor & Building & Portion surveyed & Date & Fecal deposits & Bats \\
\hline \multirow[t]{13}{*}{$100 \mathrm{D}$} & 189 & $\mathrm{RCA}^{(\mathbf{a})}$ & $8-12-93$ & No & None \\
\hline & 195 Test Tower & RCA & $8-12-93$ & No & None \\
\hline & 190 & RCA & $8-12-93$ & No & None \\
\hline & $\begin{array}{l}\text { Process Pipe Tunnel from } \\
\text { Building } 190 \text { to DR Reactor }\end{array}$ & RCA & $9-2-93$ & Yes & $\begin{array}{l}1 \text { colony of an as yet undertemined } \\
\text { species and } 1 \text { myotis (dead)(b) }\end{array}$ \\
\hline & 190DR Pit & All & $8-30-93$ & No & None \\
\hline & 181 & RCA & $8-18-93$ & No & None \\
\hline & 182 & RCA & $8-18-93$ & No & None \\
\hline & 183 & RCA & 8-18-93 & No & None \\
\hline & 1703 & Nonasbestos & $8-27.93$ & No & None \\
\hline & 1713 & All & $8-27-93$ & No & None \\
\hline & 1722 & All & $8-27.93$ & No & None \\
\hline & Intake and Outflow & none & $9-1-93$ & - & - (pipes totally submerged) \\
\hline & - & RCA & $8-16-93$ & Yes & 3 myotis (dead) (b) \\
\hline D Reactor & - & $\mathrm{RCA}$ & $8-17-93$ & No & None \\
\hline DR Reactor & - & $\operatorname{SCA}^{(\pi)}$ & $8-25-93$ & No & $\begin{array}{l}2 \text { Silver-haired bats (dead) } \text { (c) }^{(\mathrm{c})} \text { and } 1 \\
\text { Small-footed myotis (dead) }\end{array}$ \\
\hline \multirow[t]{3}{*}{ 100K East } & 183.3 Filter Bay & All & 9-13-93 & No & None \\
\hline & 165 Basement & All & 9-13-93 & No & None \\
\hline & 190 & All & 9-13-93 & No & None \\
\hline $100 \mathrm{~K}$ West & 165 Basement & All & 9-13-93 & No & None \\
\hline 100K East/100K West & Cross-Tie Tunnel & All & $9-13-93$ & No & None \\
\hline H Reactor & - & RCA & $9-3-93$ & Yes & $\begin{array}{l}7 \text { Pallid bats (dead), }{ }^{\text {(c) }} 1 \text { myotis }{ }^{(b)} \\
\text { (dead), and } 1 \text { live unidentified bat }\end{array}$ \\
\hline F Reactor & - & RCA and SCA & $9-16-93$ & Yes & $\begin{array}{l}6 \text { Pallid bats (dead), }{ }^{(c)} 1 \text { immature } \\
\text { small-footed myotis (dead), }{ }^{(c)} 3 \\
\text { myotis (dead), }{ }^{(6)} \text { and } 1 \text { unidentified } \\
\text { bat (dead) }\end{array}$ \\
\hline K West Reactor & & RCA & 9-20-93 & No & None \\
\hline K East Reactor & & RCA & $9-21-93$ & No & None \\
\hline \multirow[t]{4}{*}{200 West } & $271 U$ & $\mathbf{R C A}$ & $8-19-93$ & No & None \\
\hline & $221 \mathrm{U}$ & RCA & $8-19-93$ & No & None \\
\hline & REDOX & RCA & 8.23 .93 & No & None \\
\hline & T Plant & RCA & $8-31-93$ & No & None \\
\hline \multirow[t]{3}{*}{200 East } & $224 \mathrm{~B}$ & RCA & 8-24-93 & No & None \\
\hline & PUREX & $\mathrm{RCA}$ and $S C A$ & $8-26-93$ & No & None \\
\hline & B Plant & RCA & 9-16-93 & No & None \\
\hline Other & 274 W(Attic) & RCA & 8-25-93 & No & None \\
\hline \multicolumn{6}{|c|}{$\begin{array}{l}\text { (a) RCA = Radiological Control Areas, SCA = Surface Contaminated Areas } \\
\text { (b) Identified by dental formula } \\
\text { (c) Identified by external features } \\
\text { (d) Extensive decomposition did not permit positive identification }\end{array}$} \\
\hline
\end{tabular}

Data from the list of bats recovered as carcasses or relocated by WHC's Animal Control Operations since 1991 (see Appendix) indicate that bats are widely distributed in buildings across the Hanford Site. However, bats were most concentrated in the 200 Areas and the reactor areas. Seven species were recovered or relocated. Myotis spp. and the silver-haired bat occurred most frequently, followed by the pallid bat and western pipistrel. 


\subsection{Conclusions}

During the six-week period of this study, only some of the reactors and their support buildings were completely surveyed (Table 2). Within the reactors, subterranean tunnels, basements, and SCAs (those areas that typically reach into the highest parts of the reactors) are most likely to contain bat colonies. However, subterranean areas, often classified as confined spaces, and SCAs are often the most difficult to access for conducting bat surveys. Additionally, bat species located during this brief survey and those recovered by WHC's Animal Control Operations are relatively common compared to Townsend's big-eared bat. A greater level of effort may be required to locate this rare species. We therefore recommend that all reactors and their auxiliary buildings, or parts of reactors (particularly underground portions) that have not been surveyed, be surveyed during the primary active season of bats on the Hanford Site, i.e., June through September 1994.

Future surveys should also emphasize other buildings on the Hanford Site where bats have been located, such as those in the 200 Areas listed by WHC's Animal Control Operations (see Appendix). However, canyon buildings in the 200 Areas should be de-emphasized or excluded from future surveys. Most parts of these buildings are occupied, well-lighted, and offer few entrances for bats. The only foraging opportunities for bats in the near vicinity of the canyon buildings are the B Pond and B-63 Ditch. The B Pond and B-63 Ditch provide relatively little foraging habitat compared with the Columbia River shoreline. 


\subsection{References}

Burt, W. H., and R. P. Grossenheider. 1980. A Field Guide to the Mammals of North America North of Mexico. Houghton Mifflin Company, Boston.

Fenton, M. B., and G. P. Bell. 1981. "Recognition of Species of Insectivorous Bats by Their Echolocation Calls." J. Mamm. 62(2):233-243.

Fenton, M. B., and H. G. Merriam. 1983. "Bats of Kootenay, Glacier, and Mount Revelstoke National Parks in Canada: Identification by Echolocation Calls, Distribution, and Biology." Can. J. Zool. 61:2503-2508.

Fenton, M. B., and M. Obrist. 1990. A Practical Guide to Using a Bat Detector. Department of Biology, York University, North York, Ontario, Canada.

Fitzner, R. E., S. G. Weiss, and J. A. Stegen. 1992. Biological Assessment for Threatened and Endangered Wildlife Species Related to CERCLA Characterization Activities. WHC-EP-0510, Westinghouse Hanford Company, Richland, Washington.

Humphrey, S. R. 1992. "Bats", In Wild Mammals of North America, J. A. Chapman and G. A. Feldhamer, eds. pp. 52-70, Johns Hopkins University Press, Baltimore, Maryland.

Ingles, G. L. 1965. Mammals of the Pacific States: California, Oregon, and Washington. Stanford University Press, Stanford, California.

Jameson, E. W. and H. J. Peeters. 1988. California Mammals. University of California Press, Berkeley, California.

Thomas, J. W. 1979. Wildlife Habitats in Managed Forests, the Blue Mountains of Oregon and Washington. USDA Forest Service, Agriculture Handbook No. 553, U.S. Department of the Interior, Washington, D.C.

Thomas, D. W., and S. D. West. 1984. "On the Use of Ultrasonic Detectors for Bat Species Identification and the Calibration of QMC Mini Bat Detectors." Can. J. Zool. 62:2677-2679.

Van Zyll de Jong, C. G. 1985. Handbook of Canadian Mammals. II Bats. National Museums of Canada, Ottawa. 


\section{Appendix}

Bats Recovered as Carcasses or Relocated by Animal Control Operations, Westinghouse Hanford Company 


\section{Appendix}

\section{Bats Recovered as Carcasses or \\ Relocated by Animal Control Operations, Westinghouse Hanford Company}

\begin{tabular}{|c|c|c|c|c|}
\hline Scientific name & Common name & Number & Location & Date \\
\hline Antrozus pallidus & Pallid bat & 1 & $100 \mathrm{~F} / 105-\mathrm{F}$ & $7 / 26 / 91$ \\
\hline Lasionycteris noctivagans & Silver-haired bat & 1 & 200E/2101-M & $3 / 29 / 91$ \\
\hline " & $"$ & 1 & $300 / 3706$ & $6 / 12 / 91$ \\
\hline " & $"$ & 1 & $600 / 616$ & $6 / 27 / 91$ \\
\hline " & $"$ & 1 & $400 / 4790$ & $4 / 20 / 92$ \\
\hline$"$ & $"$ & 1 & $300 / 313$ & $4 / 23 / 92$ \\
\hline$"$ & $"$ & 1 & $200 W / 2703-W C$ & $5 / 17 / 93$ \\
\hline Myotis leibii & Small-footed myotis & 1 & 400/4713-B & $8 / 12 / 92$ \\
\hline Myotis lucifugus & Little brown myotis & 1 & $100 \mathrm{~K} / 105-\mathrm{KW}$ & $3 / 6 / 92$ \\
\hline$n$ & $"$ & 3 & $200 W / 277-W$ & $6 / 29 / 92$ \\
\hline$"$ & $"$ & 1 & $200 \mathrm{~W} / 221-\mathrm{U}$ & $8 / 6 / 92$ \\
\hline Myotis volans & Long-legged myotis & 1 & $1100 / 1171$ & $5 / 30 / 91$ \\
\hline Myotis yumanensis & Yuma myotis & 1 & $100 \mathrm{~F} / 105-\mathrm{F}$ & $5 / 21 / 91$ \\
\hline$n$ & " & 1 & $100 \mathrm{~K} / 105-\mathrm{KW}$ & $8 / 19 / 91$ \\
\hline Pipistrellus hesperus & Western pipistrel & 1 & $100 \mathrm{H} / 105-\mathrm{H}$ & $6 / 27 / 91$ \\
\hline
\end{tabular}




\section{Distribution}

No. of

Copies

\section{OFFSITE}

12 DOE/Office of Scientific and

Technical Information

\section{ONSITE}

3 DOE Richland Operations Office

R. D. Hildebrand

A5-55

M. W. Tiernan

DOE-RL Reading Room 1

15 Westinghouse Hanford Company

D. D. Blankenship

R. F. Giddings

J. E. Hodgson

D. S. Landeen

N. K. Lane

R. M. Mitchell

T. J. Ruane

M. R. Sackschewsky

J. A. Stegen

R. S. Weeks

S. G. Weiss (5)
X8-29

N3-06

$\mathrm{X} 7-02$

A5-55

H4-14

H6-01

H6-04

X3-61

H4-14

H6-02

H6-26

H6-02
No. of

Copies

29 Pacific Northwest Laboratory

J. M. Becker (5)

K6-60

C. A. Brandt (10)

$\mathrm{K} 6-60$

L. L. Cadwell

$\mathrm{K} 6-63$

G. W. Gee

K6-77

S. O. Link

K6-63

R. Mazaika

K6-60

W. H. Rickard K6-63

L. E. Rogers

R. E. Schrempf

Publishing Coordination

Technical Report Files (5)

Routing

R. M. Ecker

M. J. Graham

P. M. Irving

C. S. Sloane

P. C. Hays (last) 

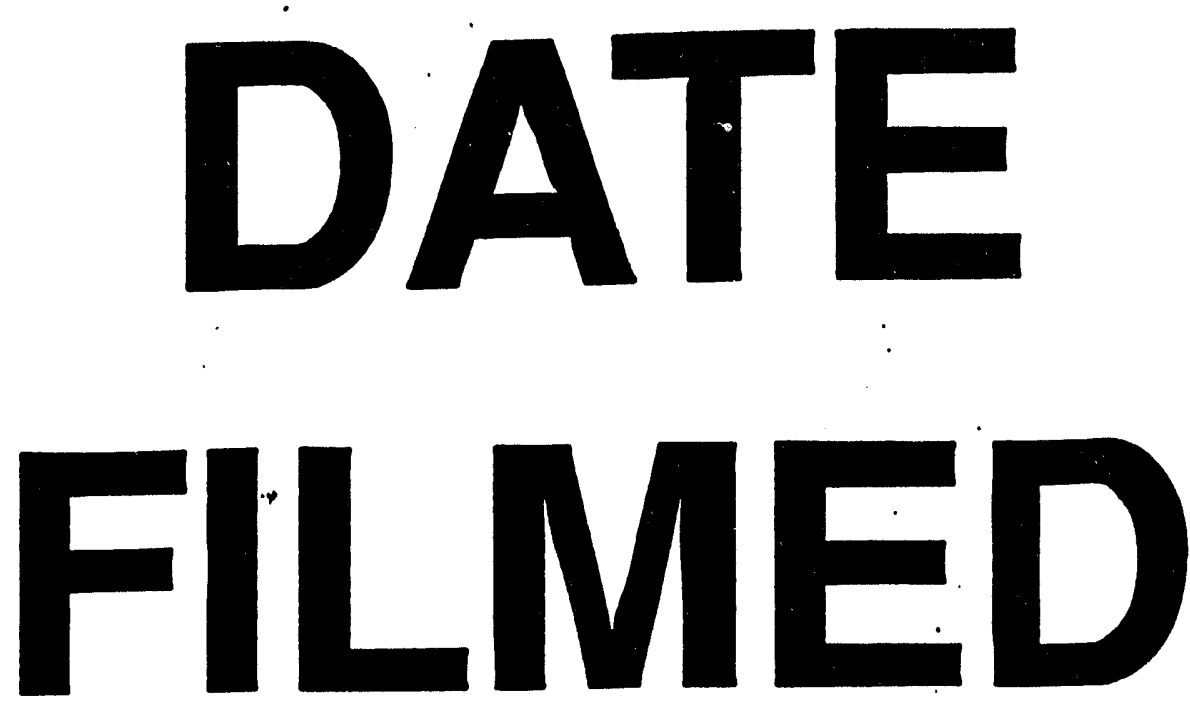

$12 / 27 / 93$
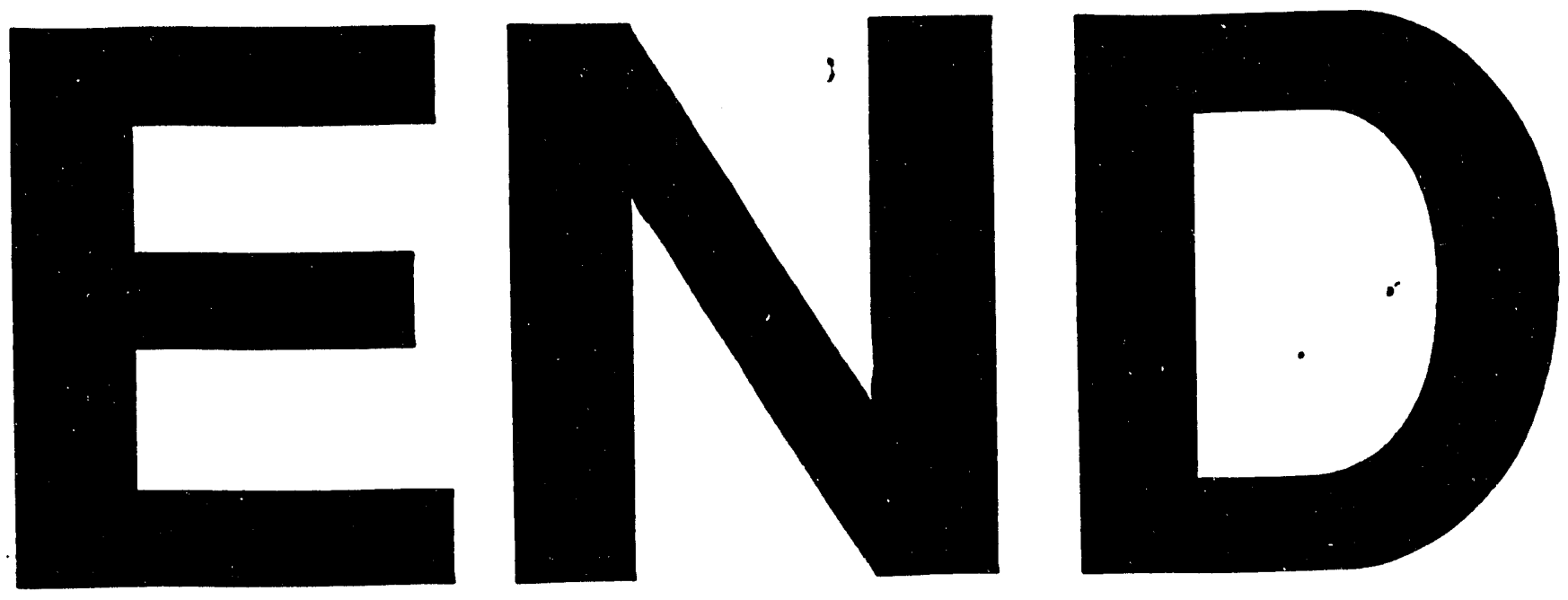


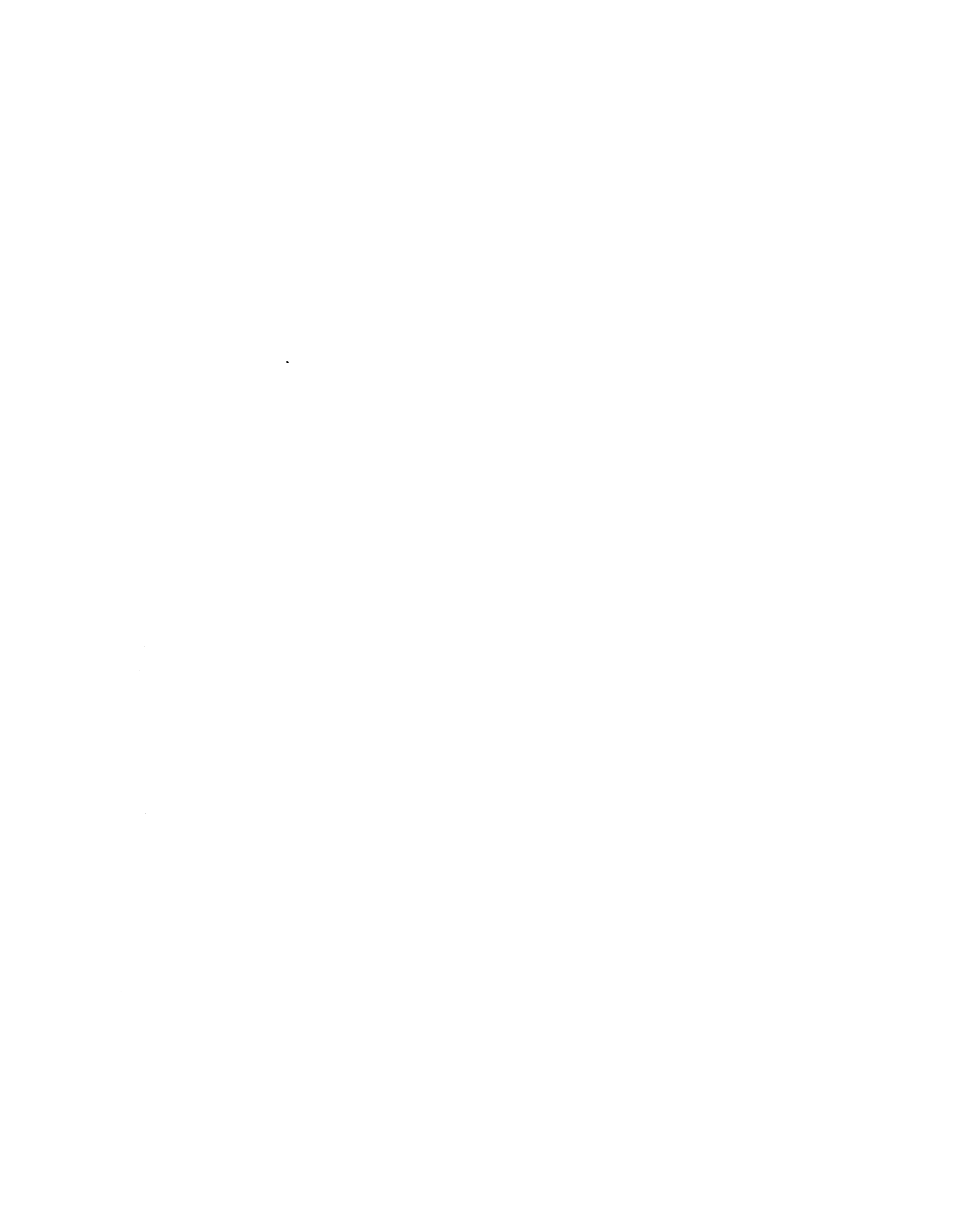

